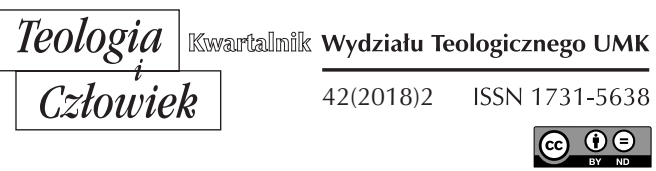

BARBARA KRZEMIŃSKA*

TORUŃ

ORCID: 0000-0002-7920-3120

\title{
BIBLIJNA NARRACJA BIOGRAFICZNA W PSYCHOTERAPII. NARRACJE BIBLIJNE O NIEPŁODNYCH KOBIETACH WOBEC NARRACJI WSPÓŁCZESNYCH KOBIET ZMAGAJĄCYCH SIĘ Z NIEPŁODNOŚCIĄ
}

DOI: http://dx.doi.org/10.12775/TiCz.2018.014

\section{WSTĘP}

Współczesność obfituje w doniesienia o wzrastającej liczbie niepłodnych kobiet i mężczyzn. Według danych Kliniki Endokrynologicznej Warszawskiego Uniwersytetu Medycznego 10-15\% par na świecie boryka się z niepłodnością ${ }^{1}$. Oznacza to, że pomimo minimum rocznego starania się o dziecko, bez stosowania środków antykoncepcyjnych, co czwarta-piąta para nie zachodzi w ciążę. Pod koniec ubiegłego wieku

* Barbara Krzemińska, magister psychologii i filologii polskiej, dyplomowany psychoterapeuta. Prowadzi gabinet psychoterapeutyczny w Toruniu, pełni funkcję biegłego sądowego w Sądzie Biskupim Diecezji Toruńskiej i Pelplińskiej. Pracuje nad stworzeniem narzędzia terapeutycznego metodą narracji biblijnej dla kobiet dotkniętych niepłodnością (przemiana1@wp.pl).

${ }^{1}$ Niepłodność: definicja, podział, metody leczenia, Klinika Endokrynologii Ginekologicznej WUM, https://endogin.wum.edu.pl/sites/endogin.wum.edu.pl/files/nieplodnosc.pdf (dostęp 29.08.2017). 
(lata osiemdziesiąte i dziewięćdziesiąte) niepłodność nie była określana mianem choroby, obecnie pogląd ten zmienił się. Niepłodność stała się istotnym problemem społecznym i przez Światową Organizację Zdrowia (WHO) uznana jest za chorobę społeczną ${ }^{2}$.

Niepłodność dotyka współczesną kobietę bardzo głęboko i we wszystkich wymiarach jej życia, gdyż uważa ona macierzyństwo za istotny element swej tożsamości. Warto się więc zastanowić, w jaki sposób można pomóc współczesnym niepłodnym zmagającym się z tym problemem, aby pomocą terapeutyczną objąć zarówno wymiar psychiczny, społeczny, duchowy, jak i biologiczny pacjentek. Czy aktualne metody terapeutyczne i medyczne wyczerpują zasób niesienia pomocy w tym zakresie?

\section{NASTĘPSTWA NIEPŁODNOŚCl}

Czym jest dla kobiety w sensie psychicznym, biologicznym, społecznym i duchowym brak możliwości posiadania dzieci? Kobieta, która nie może doczekać się potomstwa, cierpi we wszystkich wymienionych wymiarach. W obszarze psychicznym pojawia się u niej obniżony nastrój oraz występują jego wahania w przebiegu cyklu miesięcznego - od nadziei zaraz po owulacji aż po rozpacz $\mathrm{w}$ dniu pojawienia się miesiączki. Charakterystyczne są stany depresyjne, napady zazdrości, żalu czy złości, gdy dowiaduje się ona o zajściu w ciążę koleżanek bądź innych znajomych kobiet. Ponadto mogą występować stany lękowe. Największy odsetek wśród niepłodnych kobiet przejawia jednak symptomy depresji $(29,7 \%)^{3}$.

W funkcjonowaniu społecznym kobiet niepłodnych daje się zauważyć ich poczucie stygmatyzacji i winy, a także zmniejszenie poczucia wartości. Brak potomstwa wpływa również na relacje kobiety z najbliższymi - zwłaszcza z mężem, oddziałując często negatywnie na więź małżeńską. Niemożność poczęcia dziecka generuje kryzysy w małżeństwie, a odsetek rozwodów w 1996 roku, jak wskazują badania, wśród małżeństw bez dzieci $(30,7 \%)$ był najwyższy po grupie małżeństw z jednym dzieckiem $(40,5 \%)^{4}$.

${ }^{2}$ M. Bidzan, Psychologiczne aspekty niepłodności, Kraków 2006, s. 13.

3 Tamże

${ }^{4}$ J. Orzeszyna, Teologiczno-moralny aspekt niepłodności w małżeństwie, Kraków 2005, s. 7. 
Niepłodność oddziałuje też na sferę duchową człowieka, równie istotną w życiu i funkcjonowaniu osoby. W wymiarze duchowym kobiety mogą odczuwać chaos, mieć poczucie bycia karanymi przez los, Boga, Absolut: „sytuacja braku dziecka prowadzi do zmian w hierarchii wartości, a nierzadko dochodzi do utraty naczelnych wartości uzasadniających sens życia"'.

\section{POMOC PSYCHOLOGICZNA WOBEC PROBLEMU NIEPŁODNOŚCl}

Z literatury przedmiotu wynika, że psychoterapia osób cierpiących z powodu przedłużającej się niepłodności nie jest wąsko wyspecjalizowana w powyższym temacie ${ }^{6}$ - nie ma specjalistycznych terapii dla borykających się z problemem niepłodności. Pomoc psychoterapeuty opiera się zazwyczaj na leczeniu objawów nerwicowych, depresyjnych, dawaniu wsparcia i przestrzeni na odreagowanie trudnych emocji oraz odsyłaniu $z$ tym problemem do lekarza psychiatry. Na rynku psychoterapeutycznym, poza profesjonalną pomocą Fundacji „Wielkie Chcenie”, „Instytutu Nadziei” czy działaniem nielicznych indywidualnych psychoterapeutów zajmujących się fachowo pomocą w przypadku tego problemu, proponowana jest „droga na skróty"7. Chodzi o pseudopsychologiczne oddziaływania metodami New Age, w stylu: „otwórz się na energię kosmiczną, a po naszych warsztatach zajdziesz w ciążę", lub odsyłanie kobiet po krótkim czasie niezachodzenia w ciążę do skorzystania ze sztucznych metod rozrodu, co nie jest leczeniem niepłodności i wynikających z niej objawów psychopatologicznych.

\section{TERAPIA NARRACYJNA WOBEC PROBLEMU NIEPŁODNOŚCl}

Oddziaływaniem wspierającym, z którym warto zapoznać osoby dotknięte analizowanym problemem, jest szeroko rozumiana narracja. Jest

${ }^{5}$ B. Bartosz, Doświadczenie macierzyństwa. Analiza narracji autobiograficznych, Wrocław 2002, s. 47-48.

${ }^{6}$ A. Doboszyńska, J. Kuczmierowska, J. Kwaśniewska, Nadzieja na nowe życie, Kraków 2015, s. 8.

${ }^{7}$ Oblicza macierzyństwa, red. D. Kornas-Biela, Lublin 1999, s. 171. 
to pojęcie stosowane w coraz większym stopniu w socjologii, psychologii, filozofii, a nawet teologii. Narracja jako narzędzie terapeutyczne pomaga zrozumieć świat i siebie ${ }^{8}$, a poprzez to zrozumienie pozwala na zmianę dotychczasowej tożsamości. Dzięki terapii narracyjnej pacjent z pomocą terapeuty może na początku odkryć, że tworzy narracje destrukcyjne (wzmacniające problem), by w dalszej kolejności stworzyć narrację świadomą, budującą i konstruktywną dla swojej egzystencji. Narracja umożliwia dotarcie do najgłębszych sensów swojego dotychczasowego życia, uświadomienie ich sobie, a w następstwie - autonomiczne kierowanie nimi. Jest to umiejętność dana tylko człowiekowi - samoświadomość pozwalająca na przeżywanie zdarzeń własnej historii, ustosunkowanie się do nich, refleksję na ich temat, dotarcie do zrozumienia sensu i celu własnego życia ${ }^{9}$. Metoda narracji jest narzędziem wykorzystywanym nie tylko do opisywania określonego stanu rzeczy, ale coraz częściej stosuje się ją również w terapii ${ }^{10}$.

Terapia z wykorzystaniem narracji dla kobiet, które cierpią z powodu niepłodności, może być szansą na jego przewartościowanie czy też włączenie go w swoje życie dzięki nadaniu mu osobistego sensu. W terapii narracyjnej wykorzystywane są wielkie narracje, takie jak mity, eposy, księgi religijne, baśnie. To właśnie te uniwersalne historie mogą pomóc w odnalezieniu przez osobę doświadczającą trudnej sytuacji własnej opowieści, która „przemawiając do niej”, pozwoli nadać nowe znaczenie traumatycznemu wydarzeniu życiowemu, zrozumieć je i zasymilować w swoim życiu ${ }^{11}$.

8 J. Trzebiński, Narracja jako sposób rozumienia świata, Gdańsk 2002, s. 22.

9 A. Cierpka, Narracje rodzinne w procesie kształtowania się tożsamości człowieka, w: Narracja koncepcje i badania psychologiczne, Warszawa 2004, s. 117.

${ }^{10}{ }^{0}$ Terapia narracyjna narodziła się w latach osiemdziesiątych XX wieku w Australii i Nowej Zelandii, a za twórców tego podejścia uważa się Michaela White’a oraz Davida Epstona, którzy odkryli, że istnieją związki pomiędzy tym, jak dana osoba opisuje siebie i swoje życie, a tym, jak doświadcza je i rozumie. Głównym założeniem terapii narracyjnej jest nadawanie przez ludzi sensu swoim doświadczeniom, co właśnie następuje poprzez opowiadanie historii przez pacjentów. A. Morgan, Terapia narracyjna. Wprowadzenie, Warszawa 2011.

${ }_{11}$ M. Straś-Romanowska, B. Bartosz, M. Żurko, Badania narracyjne w psychologii, Warszawa 2010, s. 19. 


\section{NARRACJA BIBLIJNA WOBEC PROBLEMU NIEPŁODNOŚCl}

Kluczowym zagadnieniem, któremu trzeba przyjrzeć się ze względu na podejmowany temat, jest narracja biblijna i możliwość wykorzystania jej w psychoterapii kobiet dotkniętych niepłodnością. Narracja biblijna czy inaczej hermeneutyczna metoda opowiadania - stanowi najnowszy nurt we współczesnej biblistyce i rozwija się na świecie mniej więcej od końca lat siedemdziesiątych i początku osiemdziesiątych ${ }^{12}$. Natomiast w polskiej literaturze biblijnej metoda ta, nazywana także krytyką narracyjną (również: narracji lub narratywną), znana jest od kilkunastu lat ${ }^{13}$. Jak podaje Papieska Komisja Biblijna, najważniejszymi i kluczowymi elementami narracji biblijnej są „elementy tekstu, które dotyczą intrygi, postaci i punktu widzenia narratora, analiza narracyjna bada sposób, $\mathrm{w}$ jaki historia zostaje opowiedziana, by wciągnąć czytelnika w «świat opowiadania» i jego system wartości”'14.

Teksty biblijne, takie jak przypowieści, opowiadania historyczne, opowiadania o cechach kronikarsko-biograficznych, spełniają warunki narracyjności i można poddać je analizie narracyjnej. Najistotniejszymi elementami opowiadań biblijnych, jako tekstów narracyjnych, nie jest przebieg ich wydarzeń, ale sposób, w jaki narrator opowiada historię i czy przez to opowiadanie dzieją się przed oczami czytelnika transformacje typu: czasowego, przestrzennego, sytuacyjnego i psychologicznego. Transformacja taka w znaczeniu nieodwracalnej zmiany sytuacji będzie klasyfikowała tekst biblijny jako tekst spełniający wymogi narracyjne ${ }^{15}$. Odbiorca poprzez czytanie tekstu biblijnego nie tyle powinien śledzić przebieg zdarzeń, co odkrywać złożoność fabuły wraz z historią życia jej bohaterów. Dzięki tym transformacjom czytelnik ma szansę odczytać sens egzystencjalny tekstu biblijnego skierowany do niego, a dotykający jego aktualnej sytuacji życiowej. Istotę podmiotowego oddziaływania narracji

12 Z. Pawłowski, Hermeneutyczna metoda opowiadania we współczesnej egzegezie, „Collectanea Theologica” 62 (1992) 1, s. 5-17.

13 S. Szymik, Współczesne modele egzegezy biblijnej, Lublin 2013, s. 59.

${ }^{14}$ Interpretacja Biblii w Kościele. Dokument Papieskiej Komisji Biblijnej z komentarzami biblistów polskich, red. R. Rubinkiewicz, „Rozprawy i Studia Biblijne”, t. 4, Warszawa 1999, s. 38.

15 S. Szymik, Współczesne modele, s. 15. 
biblijnej tak opisuje Zdzisław Pawłowski: „zdolność transformacji natomiast ujawnia się z chwilą, kiedy procesowi czytania zaczyna towarzyszyć wyznawanie swojego życia $\mathrm{w}$ sensie augustyńskiego confessio vitae. Od tego momentu czytelnik śledzi już nie tylko fabułę, zawartą w opowiadaniu, ale przy jej pomocy uczy się sam stawać narratorem swojego własnego życia. Zmierza tym samym do uchwycenia całości swego doświadczenia w formie narracyjnej tożsamości, która ustanawia jego autentyczną podmiotowość. Dochodzimy bowiem do tego, kim jesteśmy, tylko wtedy, gdy potrafimy rozpoznać samych siebie w opowieściach, które sami o sobie opowiadamy lub słyszymy od innych" ${ }^{16}$.

Skoro Biblia jako księga ponadczasowa, a przez to zaliczana do wielkich narracji, opisuje silne i zindywidualizowane zmagania bohaterek z problemem przedłużającej się niepłodności: Rebeki, Anny, Sary, Szunemitki (kobiety z Szunem), Racheli, matki Samsona czy św. Elżbiety, czyż nie może stać się źródłem zrozumienia, inspiracji, odnalezienia sensu dla współczesnej kobiety w jej indywidualnej historii? Narracje biblijne dotyczące dramatu braku dziecka mogą wywołać w niej pytania poruszające głęboko tożsamość: kim jestem?, jaki jest sens mojego życia?, jaki mam na nie wpływ? Szukając odpowiedzi na te fundamentalne kwestie, współczesna niepłodna może wprowadzić świadomy porządek zarówno w myśleniu o swojej niepłodności, przeżywaniu jej, jak i w podejmowaniu związanych z nią działań. Jednak przede wszystkim może nadać temu doświadczeniu nowy sens ${ }^{17}$.

\section{HISTORIE BIBLIJNYCH KOBIET W SKUŻBIE TERAPII NARRACJĄ BIBLIJNĄ}

Narracja w terapii jest najskuteczniejsza wtedy, gdy pobudza jednostkę do odkrywania indywidualnych sensów. Metody narracji biblijnej nie mogą być więc podane jako uniwersalny sposób dla wszystkich kobiet zmagających się $\mathrm{z}$ niepłodnością. Terapeuta nie powinien ingerować

16 Z. Pawłowski, Opowiadanie, Bóg i początek: teologia narracyjna Rdz 1-3, „Rozprawy i Studia Biblijne” 13, s. 229.

${ }_{17}$ M. Straś-Romanowska, B. Bartosz, M. Żurko, Psychologia małych $i$ wielkich narracji, Warszawa 2010, s. 33. 
w opowieści pacjentki, a tym bardziej w odkrywanie przez nią własnych, subiektywnych znaczeń w kontekście wielkich narracji. „Dzięki narracji można prawdopodobnie uzyskać dane bliższe autentycznemu doświadczeniu wewnętrznemu jednostki"18. Ważne jest więc stworzenie takiego narzędzia biblijnej terapii biograficznej, które będzie jak najbardziej wszechstronne w swoim docieraniu do indywidualnej interpretacji tekstu przez każdą z kobiet, a w następstwie - jej subiektywnego przeżywania i autonomicznego oceniania poznanych faktów. Istotne jest, by historie te poruszały struny tożsamości zarówno społecznej, podmiotowej (psychologicznej), duchowej, jak i biologicznej kobiety, co umożliwiałoby objęcie terapeutycznym oddziaływaniem całej osoby. A przecież bohaterki historii biblijnych były takimi samymi kobietami jak współczesne kobiety. Chociaż osadzone w innym kontekście kulturowo-społecznym i odległych czasach, miały identyczne potrzeby w obszarze niespełnionego macierzyństwa, co generowało $\mathrm{w}$ nich stany emocjonalne, a wręcz zaburzenia psychiczne tożsame z reakcjami niepłodnych kobiet dzisiaj. Doprowadzało to niektóre $\mathrm{z}$ nich do poszukiwania rozwiązań przypominających współczesne działania - zastępcze macierzyństwo (oddelegowanie służących do rodzenia dzieci poczętych z ich mężów), adopcję czy wspomaganie płodności specyfikami zielarskimi (dziś farmakologia) ${ }^{19}$. Przez brak potomstwa niewiasty te zaczynają być postrzegane jako takie, którym Dawca Życia nie pobłogosławił, więc czują się one gorsze i zhańbione na tle swojego środowiska. Także $\mathrm{w}$ relacjach $\mathrm{z}$ mężami bohaterki te przeżywały stany i sytuacje jakże podobne do zdarzających się u dzisiejszych bezdzietnych małżeństw - bezradność i wycofanie męża wobec zaistniałego problemu, wzajemne obwinianie się czy kompletna utrata nadziei i niedowierzanie, że to może się pomyślnie zakończyć (postawa rezygnacji małżonków wobec faktu stania się rodzicami).

Innym, niezmiernie ważnym aspektem biblijnych postaci kobiecych, który dotkliwie dotyczył problem braku potomstwa, jest kwestia ich przemiany wewnętrznej w przebiegu ich historii życia. Większość z nich szukała rozwiązania problemów egzystencjalnych przez zwrócenie się prędzej

18 M. Straś-Romanowska, B. Bartosz, M. Żurko, Badania narracyjne, s. 25.

19 A. Doboszyńska, J. Kuczmierowska, J. Kwaśniewska, Nadzieja na nowe życie, s. 234 . 
czy później ze swoim bólem i udręką do Tego, który jest. W następstwie doprowadzało to do rekonstrukcji ich życia - swoistej przemiany tożsamości. W dalszej części niniejszego artykułu proponuję więc przyjrzeć się kierunkom terapii narracyjnej, które wytycza Biblia jako wielka narracja na temat niepłodnych kobiet, nie formułując dosłownych sensów wprost.

\subsection{ZMIANA NARRACJI NEGATYWNYCH W ZETKNIĘCIU Z HISTORIAMI O NIEPŁODNOŚCl BOHATEREK}

Potem żona jego, Elżbieta, poczęła i kryła się [z tym] przez pięć miesięcy, mówiąc: „Tak uczynił mi Pan wówczas, kiedy wejrzał łaskawie, by zdjąć ze mnie hańbę wśród ludzi”. (Łk 1, 24-25)20

W historiach niepłodnych kobiet biblijnych najbardziej uderza pewna znamienna sytuacja powtarzająca się u prawie wszystkich $\mathrm{z}$ nich: Sary, Rebeki, Racheli, żony Manoacha, Anny, św. Elżbiety, poza jedną Szunemitką. Kobiety te po długim czasie niepłodności rodzą wyjątkowe w historii Izraela dzieci: patriarchów (Sara rodzi Izaaka, Rebeka - Jakuba, a Rachela - Józefa Egipskiego), proroków (św. Elżbieta rodzi Jana Chrzciciela, a Anna staje się matką Samuela) lub nazirejczyków (czyli namaszczonych od łona matki mężów Bożych, obdarowanych niezwykłą siłą, a działających pod wpływem Ducha Bożego; żona Manoacha rodzi Samsona, Sdz 13, 7). Jak widać w życiu tych bohaterek, długie czekanie na potomstwo - trwające czasem kilkadziesiąt lat (Sara zachodzi w ciążę w wieku 89 lat, Rebeka po 20 latach od zawarcia małżeństwa z Izaakiem rodzi bliźniaki - Jakuba i Ezawa, św. Elżbieta w „sędziwym wieku”, czyli można przypuszczać, że po 50. roku życia, staje się matką Jana Chrzciciela) kończy się wielkim szczęściem, a wręcz błogosławieństwem. $\mathrm{Na}$ świat przychodzi bowiem wyjątkowe, wyróżnione przez Stwórcę dziecko. Można powiedzieć, że to, co było największym przekleństwem i hańbą tych kobiet, staje się ich największą chlubą i radością ${ }^{21}$.

${ }^{20}$ Wszystkie cytaty biblijne w niniejszym artykule pochodzą z wydania: Biblia Tysiąclecia. Pismo Święte Starego i Nowego Testamentu, Wydawnictwo Pallottinum, Poznań 1982.

${ }^{21}$ Franciszkańska3.pl, Niełatwe macierzyństwo biblijnych kobiet, http://fra3mobile. fra3test.ceti.pl/ (dostęp 21.05.2018). 
Warto pokusić się o pewne wnioski na temat tych zaskakujących sytuacji w życiu biblijnych bohaterek. Czy długie oczekiwanie na potomstwo niejako formowało te kobiety i ich mężów do przyjęcia tak wyjątkowego dziecka? Zapewne niepłodność nie byłaby wówczas karą, hańbą, przekleństwem, ale wręcz błogosławieństwem i niejako wybraniem ich na matki mężów Bożych. Być może wieloletnia niepłodność była niejako przygotowaniem, formą oczyszczenia rodziców tak wartościowego i cennego dla świata dziecka? Długie oczekiwanie na potomstwo, a także urodzenie syna w późnym wieku często kończy się w Biblii interwencją Boga - poczęciem wbrew ludzkiej logice; tak było w przypadku Sary (matki Izaaka), Racheli (matki Józefa i Beniamina) czy też nienazwanej matki Samsona, Hanny (matki Samuela) i Elżbiety (matki Jana Chrzciciela). W każdym z wyliczonych przypadków narodzone dziecko miało odegrać wyjątkową rolę w historii Izraela. Co miałoby to oznaczać dla współczesnych kobiet oczekujących bezskutecznie przez wiele lat na dziecko? Jak mogą one wykorzystać metanarracje biblijne w służbie swoich jednostkowych narracji na temat niepłodności? Wiele kobiet dziś czuje się winnymi i ukaranymi za swoje dotychczasowe życie, wybory, czyny właśnie niepłodnością. W niektórych współczesnych wspólnotach i kręgach religijnych panuje opinia, że jeśli ma się dużo dzieci, to Pan Bóg błogosławi ich rodzicom, a jeśli dzieci brak, to być może jest coś nieprawidłowego w tej osobie lub jej rodzinie. Oczywiście nie należy w taki uproszczony i skrajny sposób patrzeć na niepłodność - jako na przekleństwo, czyli: „nie masz dzieci ponosisz za coś karę”, a z drugiej strony jako na błogosławieństwo: „nie masz długo dzieci - urodzisz w końcu dziecko wyjątkowe dla historii, kraju, Kościoła, społeczności”. Ważne, aby współczesne niepłodne kobiety dotknęła pewna odkrywcza myśl, obalająca destrukcyjne narracje na temat ich niepłodności. By niepowtarzalnej narracji szukały w historiach własnej niepłodności, a nie opierały się na cudzych narracjach, przyjmując bezkrytycznie opinie na temat bycia niepłodną od ludzi z zewnątrz ${ }^{22}$, tym bardziej że zewnętrzne narracje zawsze pozbawione są kontekstu osobistego. Ocena ludzi z zewnątrz jest nierzadko schematyczna, płytka, sztampowa i nie ma nic wspólnego z jednostkowym sensem życia kon-

${ }^{22}$ M. Straś-Romanowska, Na tropach psychologii jako nauki humanistycznej, Warszawa 1995, s. 29. 
kretnej osoby. Widać to w historii 89-letniej Sary, zachodzącej według obietnicy Boga w ciążę, mimo że „nie miewała przypadłości właściwej kobietom" (Rdz 18, 11-12). Tak samo widoczne jest to osobiste przeznaczenie w życiu św. Elżbiety i Zachariasza, którzy nie umierają bezpotomnie jako następcy rodu kapłańskiego, pomimo wielu wcześniejszych lat życia w opinii zhańbionych społecznie, bo pozbawionych potomstwa. Podobnie sytuacja wygląda z Rachelą czy Anną (matką Samsona) - poniżane jako bezdzietne przez drugie (płodne) żony swoich mężów (odpowiednio: Leę i Peninę), doświadczają w końcu zrodzenia własnymi siłami synów. Rachela doczekuje się dwóch synów: Józefa i Beniamina (niestety, rodząc go, umiera), Anna zaś po pierworodnym Samuelu rodzi jeszcze pięcioro dzieci - trzech synów i dwie córki.

Czytając te narracje z zupełnie zaskakującym zwrotem akcji w historii niepłodności matriarchiń biblijnych, dzisiejsza niepłodna kobieta może odkrywać własny, jednostkowy sens niepłodności²3. Wartości egzystencjalne i religijne odgrywają ważną rolę dla zmiany narracji z destruktywnej na konstruktywną, budującą na nowo sens życia poszczególnych osób. Pozwalają one odpowiedzieć jednostce na pytanie na temat własnej narracji - „czy żyje ona moimi narracjami, czy narracjami innych - ludzi z zewnątrz. Czy żyję własnym życiem, czy też «przesiąknięty jestem» cudzymi historiami" 24 .

Istotne jest więc dla zdrowia psychicznego każdej kobiety - która pełna jest poczucia winy, naznaczenia społecznego czy odczucia bycia karaną z tego powodu, że nie zachodzi w ciążę - by przyjrzała się, jakie narracje „sprzedają i wdrukowują" jej członkowie rodziny, sąsiedzi, znajomi, lekarz, wspólnota. Być może są to takie narracje, które wywołują objawy psychopatologiczne ${ }^{25}$. Może być też tak, że patologiczne poczucie winy, porównywanie się z płodnymi kobietami czy odczucie wyobcowania społecznego będą wzmacniały w kobiecie nie tylko zewnętrzne narracje pochodzące od jej otoczenia (np. „zbyt długo odkładałam zajście w ciążę i teraz już nie będę miała dziecka”, „za mało wyjeżdżamy z mężem

${ }^{23}$ M. Straś-Romanowska, $\mathrm{Na}$ tropach, s. 54.

${ }^{24}$ U. Tokarska, Terapia narracyjna: założenia teoretyczne, metody pracy, obszary zastosowań, „Acta Universitatis Wratislaviensis” 2263 (2000), s. 189.

25 E. Dryll, A. Cierpka, Psychologia, dialogowość, pogranicza, Warszawa 2011, s. 34 . 
na urlopy i dlatego mamy problem z płodnością"). Szansą na zmianę negatywnego podejścia do siebie i swojej historii jest właśnie terapia narracyjna, gdzie pacjentka będzie mogła uświadomić sobie negatywne narracje wokół osobistej niepłodności, zarówno te zewnętrzne - pochodzące od innych, jak i własne narracje wewnętrzne, które nosi w sobie od lat. A właśnie dzięki spotkaniu podczas terapii z historiami niepłodnych biblijnych bohaterek kobieta współczesna może odszukać nowe, budujące narracje na temat niepłodności, które będą ją wspierały i uwalniały od niepotrzebnego cierpienia w przeżywanym problemie.

\subsection{WGLĄD W SIEBIE, POCZUCIE BYCIA ZROZUMIANĄ, ODREAGOWANIE TRUDNYCH EMOCJI POPRZEZ IDENTYFIKACJĘ Z POSTAWAMI BOHATEREK}

Ona zaś smutna na duszy zanosiła do Pana modlitwy i płakała. (1 Sm 10)

Sara, Rebeka, Rachela, żona Manoacha, Szunemitka, Anna, św. Elżbieta - mimo że są bohaterkami świętej księgi, jaką jest Biblia, były zwyczajnymi osobami o ludzkich postawach i reakcjach. Nie posiadały nadzwyczajnych mocy jak niektóre z ich dzieci (Samson, Jan Chrzciciel), a nawet większość z nich nie miała daru słyszenia głosu Boga (poza Sarą i Rachelą). Kobiety te w swoich zmaganiach z niepłodnością, szczególnie na początku własnej drogi cierpienia, odwoływały się do ludzkich czynów i rozwiązań tego problemu. Sara i Rachela wpadły na pomysł zastępczego macierzyństwa i skłoniły swoich mężów, aby ci, współżyjąc z niewolnicami, uczynili je ciężarnymi. W przypadku Sary to niewolnica Hagar staje się surogatką. Ponieważ Pan zamkną mi łono, abym nie rodziła - powiedziała do Abrahama - zbliż się do mojej niewolnicy; może z niej będę miała dzieci $(\operatorname{Rdz} 16,2)$. Rachela idzie w realizacji bycia zastępczą matką jeszcze dalej i nakazuje swojej niewolnicy urodzić dla siebie potomka na jej kolanach (Mam niewolnicę Bilhę, zbliż się do niej, aby urodziła dziecię na moich kolanach; chociaż w ten sposób będę miała od ciebie potomstwo ( $\mathrm{Rdz} 30,3-4)$ oznajmia Jakubowi ${ }^{26}$. Również mąż Sary, Abraham, jeszcze przed naro-

${ }^{26}$ K. Romaniuk, Macierzyństwo w Biblii, Warszawa 1998, s. 56; Macierzyństwo, red. J. Augustyn, Kraków 1998, s. 56. 
dzeniem Izmaela - syna z Hagar, zastanawia się nad innym rozwiązaniem problemu braku potomstwa. Chce zaadoptować Eliezera Damasceńczyka - niewolnika, aby jego uczynić swym spadkobiercą. Jak widać, rozwiązania te są nie tylko ludzkimi sposobami na przedłużenie rodziny, ale również współczesnymi drogami wyjścia z problemu bezdzietności. Współczesne pary, nie mogąc latami doczekać się potomstwa, szukają pomocy w adopcji, jak również w zastępczym macierzyństwie, czyli oddają zapłodnioną pozaustrojowo komórkę jajową właśnie surogatce, która donosi i urodzi im dziecko.

Inną, jakże zwyczajną reakcją jednej z kobiet biblijnych na problem niepłodności, jest uciekanie się do ziołolecznictwa (współcześnie: farmaceutyków). Rachela jest chyba najbardziej aktywna i pomysłowa w poszukiwaniach sposobu na poczęcie dziecka. Gdy Ruben - syn Lei (drugiej żony Jakuba, a zarazem siostry i największej rywalki Racheli), przynosi swojej matce ziele mandragory jako specyfik pomnażający płodność, Rachela niemalże rzuca się na zioło i chce je przywłaszczyć: Wtedy Rachela rzekła: „Daj mi mandragory syna twego” (Rdz 30, 14).

Inne biblijne bohaterki, szczególnie Anna - matka Samsona i zapewne św. Elżbieta, uciekają się do modlitwy jako sposobu na zmianę swojej niepłodności. Czyni tak również mąż Rebeki - Izaak, który przez dwie dekady modli się o potomstwo dla swojego małżeństwa. Ten sposób nie zawodzi. W obu przypadkach następuje poczęcie dziecka, a u Izaaka i Rebeki - bliźniąt. W modlitwie, szczególnie Anny, widoczna jest postawa wielkiej ufności, żarliwości i całkowitego oddania Bogu swojego nieszczęścia i boleści, jakimi Anna określa brak potomstwa, kiedy tłumaczy kapłanowi Heliemu swoje postępowanie: Nie, panie mój. Jestem nieszczęśliwą kobietą, a nie upiłam się winem ani sycerą. Wylałam dusze moja przed Panem. Nie uważaj swej służebnicy za córkę Beliala, gdyż z nadmiaru zmartwienia i boleści duszy mówiłam cały czas (1 Sm 1, 15-16).

Opisane postaci biblijne są typami bohaterów dynamicznych i złożonych (ang. round character) ${ }^{27}$, pełnych pasji i woli walki w realizacji swojego pragnienia macierzyństwa (szczególnie Rachela i Anna - matka Samsona), co oznacza, że spełniają wymogi dobrej narracji. Według kry-

${ }_{27}$ R. Bartnicki ks., K. Kłósek, Metody interpretacji Nowego Testamentu, Kraków 2014, s. 225. 
teriów dobrej narracji w perspektywie badawczej dobra narracja ma bohatera, a im bardziej wyrazista jest artykulacja postaci bohatera, tym wyższy jest stopień narracyjności tekstu. Innym kryterium poza wyrazistością charakteru jest wymóg, by bohater ten był osadzony w społeczeństwie, miał określoną rolę społeczną bądź pozycję czy prawa. Poza tym osobowość bohatera wymaganego w dobrej narracji winna przejawiać się w jego walce o miejsce w społeczeństwie - takie poglądy na temat istoty dobrej narracji prezentuje Jerome S. Bruner ${ }^{28}$. Narracja najbardziej wartościowa dla psychoterapii to taka, która dzięki uzyskanemu wglądowi uporządkuje wewnętrzne doświadczenie osoby i nada jej sens poprzez utożsamienie się $\mathrm{z}$ bohaterem. W historii bohaterek narracji biblijnych kobiety niepłodne mogą odnaleźć swoje historie zmagania się z niepłodnością - poprzez identyfikację z konfliktami, emocjami, zachowaniami, sposobami rozwiązywania problemów kobiet w Biblii. To odzwierciedlenie przez bohatera narracji spełnia podstawową funkcję psychoterapii, jaką jest poczucie bycia zrozumianym w swoich osobistych zmaganiach i problemach.

Niezmiernie ważną funkcją biblijnej narracji biograficznej w psychoterapii niepłodnych jest uwolnienie i odreagowanie trudnych emocji poprzez identyfikację z emocjami bohaterek. Gdy uważnie prześledzimy opis biblijny świata emocjonalnego postaci, możemy spotkać się z całą gamą uczuć, napięć, a wręcz objawów psychopatologicznych, składających się na współcześnie opisywane zaburzenia psychiczne. Chodzi głównie o Sarę, Rachelę i matkę Samsona - Annę. Pierwsza z wymienionych cierpi według autorki niniejszego artykułu na rodzaj dystymii - przewlekłą depresję z objawami osiowymi, takimi jak: częściowa rezygnacja, anhedonia, bezsens, poczucie beznadziei, osłabiona motywacja. Do tego stopnia ogarnia ją ten stan patologiczny, że nie potrafi już przyjąć i uwierzyć obietnicy Bożej, a wręcz jej nie dowierza: Uśmiechnęła się więc do siebie i pomyślała: „Teraz, gdy przekwitłam, mam doznawać rozkoszy i mój mąż starzec” (Rdz 18, 12). Sara jest zrezygnowana, całkowicie brakuje jej nadziei na to, że będzie matką. W wieloletniej depresji jest także matka Samuela, Anna, w czasie swojej niepłodności. Jest to jednak inny rodzaj depresji - klasycznej, tzw. większego zaburzenia depresyjnego ${ }^{29}$, z głównymi objawami osiowymi,

${ }^{28}$ M. Straś-Romanowska, B. Bartosz, M. Żurko, Badania narracyjne, s. 22.

${ }^{29}$ Kryteria diagnostyczne $z$ DSM-5, 2015, s. 90-91. 
takimi jak: brak łaknienia, ból psychiczny, płaczliwość, smutek, rozpacz, zmartwienie. Nie cieszy jej już małżeństwo z Elkaną, mimo że jest jego ukochaną żoną. Depresja ogarnia ją tak, że nie pozostaje jej nic innego, jak szukanie uzdrowienia u samego Stwórcy. Inny rodzaj objawów klinicznych prezentuje Rachela: zazdrość, wahania nastroju, szantażowanie swojego męża samobójstwem: Spraw, abym miała dzieci, bo inaczej przyjdzie mi umrzeć! (Rdz 30,1), kompulsywne zachowania przejawiające się w jej ciągle to nowych działaniach mających uczynić z niej matkę (oddelegowywanie swojej służącej do rodzenia dzieci, szukanie pomocy na bycie płodną w zielu mandragory). Opis nasuwa na myśl osobę cierpiącą z powodu nerwicy natręctw. Być może Rachela tak bardzo się bała, że nigdy nie zostanie matką, że lęk próbowała stłumić poprzez wszystkie te chaotyczne działania. Jak widać, zaburzenia, które prezentowały trzy wymienione przez mnie kobiety z Biblii - Sara, Rachela i Anna, są często tożsame $\mathrm{z}$ objawami współczesnych kobiet leczących się z powodu braku dziecka. Do gabinetów trafiają najczęściej pacjentki z objawami lękowymi, elementami nerwicy natręctw czy depresją. Nierzadko korzystają z leczenia psychiatrycznego, co nie oznacza oczywiście, że „zwariowały”, tylko że brak macierzyństwa głęboko zaburzył ich równowagę psychiczną. Poza leczeniem farmakologicznym, które redukuje objawy psychopatologiczne, ale nie leczy źródła problemu, trzeba dać tym osobom narzędzie terapeutyczne, dzięki któremu objawy zostaną zredukowane lub wręcz przestaną istnieć. Poczucie bycia zrozumianą w swoim problemie (odczucie: „nie jestem już sama”), wgląd porządkujący wewnętrzny chaos, a także odreagowanie emocjonalnie niezwykle silnych i bolesnych uczuć daje właśnie terapia narracją ${ }^{30}$. Uporządkowanie wewnętrznych doświadczeń wokół problemu na poziomie poznawczym automatycznie porządkuje również świat emocji. Jak zatem widać, poznanie tych obszarów biblijnych żon (uczuć i objawów) może wnieść w życie kobiet poddanych terapii narracją biblijną nie tylko wgląd wewnętrzny, ale też odreagowanie tych trudnych i silnych emocji odczuwanych przez kobiety latami.

30 M. Molicka, Biblioterapia i bajkoterapia, Poznań 2011, s. 119-121. 


\subsection{ODNALEZIENIE SIEBIE W TOŻSAMYCH REAKCJACH RODZINNYCH I SPOŁECZNYCH DOTYKAJĄCYCH BOHATERKI}

I rzekł do niej jej mąż, Elkana: „Anno, czemu płaczesz? Dlaczego nie jesz? Czemu się twoje serce smuci? Czyż ja nie znaczę dla ciebie więcej niż dziesięciu synów?”.(1 Sm 1,8)

Niepłodne żony biblijne mają w większości przypadków mężów, którzy nie wspierają ich w problemie niepłodności (poza Izaakiem, który modli się o poczęcie dla siebie i Rebeki, oraz Abrahamem, który jako mąż wiary nigdy nie zwątpił w obietnicę Najwyższego, że on i Sara zostaną obdarowani własnym potomstwem). Jakub - mąż Racheli, jak i Elkana - mąż Anny, pozostają bierni, a wręcz odcinają się od problemu przez niezrozumienie reakcji emocjonalnych małżonek, wynikających z wieloletniego braku dziecka. Jakub gniewnie krzyczy na Rachelę, że to nie on odmawia jej potomstwa, wskazując przez to na Wszechmogącego jako sprawcę tejże sytuacji, co mogło tylko wpędzić Rachelę w poczucie winy. Natomiast Elkana (mąż Anny) z niezrozumieniem podszytym bezradnością, a może i nutą pretensji, pyta żonę, czy on nie znaczy dla niej więcej niż nawet dziesięciu synów, jakby sugerując, że powinna się nim zadowolić w miejsce swojej niespełnionej potrzeby macierzyństwa. To z kolei może potęgować w Annie poczucie samotności, niezrozumienia i braku wsparcia od najbliższych, tym bardziej że Penina - druga żona Elkany, naśmiewa się z niej i poniża ją z powodu niepłodności: Jej współzawodniczka przymnażała jej smutku, aby ja rozjątrzyć z tego powodu, że Pan zamknąt jej łono (1 Sm 1, 6).

Kobiety współczesne od lat starające się bezskutecznie o dziecko mogą czuć się w relacjach ze swoimi mężami czy bliską rodziną (matką, siostrą, szwagierką, sąsiadką lub znajomą) podobnie jak Anna. Mają poczucie napiętnowania społecznego, niższości, niezrozumienia przez najbliższych, czyli tych, od których tak naprawdę potrzebują wsparcia i pomocy ${ }^{31} 32$. Niektóre $z$ nich spotykają się zapewne $z$ okrutnymi reakcjami osób z otoczenia, krytyką, wyśmianiem czy wyszydzeniem ich niepłodności, jak w przypadku reakcji Peniny wobec Anny. Czasem bę-

${ }^{31}{ }^{32}$ B. Pawelec, W. Pabian, Niepłodność. Pomoc medyczna i psychologiczna, Sopot 2012, s. 93. 
dzie to wścibski wuj, który po raz kolejny pytając bezdzietną parę: „kiedy będzie dzidziuś", zasugeruje z przytykiem, że ,jakby się nie udawało, to ja mogę pomóc". A kiedy indziej - co jest pewnie najboleśniejsze dla kobiety stęsknionej dziecka - cios padnie ze strony męża, który nie wytrzymując napięcia oczekiwania, obwini kobietę, stwierdzając: „Za dużo byś chciała mieć. Masz dobrą pracę, wspaniałego męża, dom, samochód. W życiu nie można mieć wszystkiego". To słowa obwiniające, bez cienia zrozumienia dla cierpienia żony, niczym słowa Jakuba wobec Racheli. W przytoczonych wyżej opowieściach biblijnych - czyli w historiach Racheli i Jakuba, Anny i Elkany, Manoacha i jego żony, św. Elżbiety i Zachariasza, a także Szunemitki i jej męża, to kobiety są na pierwszym planie. Natomiast ich mężowie są bierni, wycofani, zalęknieni, a także nie wierzą w to, że zostaną ojcami. Widać to w przypadku Manoacha i Zachariasza, którzy na tyle wątpią w obietnicę posłańca zwiastującego narodzenie dziecka, że zamiast nadziei (wartości duchowej) wybierają zrozumienie (wartość intelektualną) $)^{32}$. Zachariasz za to, że nie uwierzył, traci mowę do czasu narodzin Jana, a Manoach obawia się o to, że zginie wraz z żoną po objawieniu się anioła zwiastującego narodzenie Samsona, gdy mówi: „Z cała pewnościa pomrzemy, bowiem ujrzeliśmy Boga”. Żona mu odpowiedziała: „Gdyby Pan miał zamiar pozbawić nas życia, nie przyjąłby z rąk naszych całopalenia $i$ ofiary pokarmowej ani też nie okazałby nam tego wszystkiego, ani też nie objawiłby nam teraz takich rzeczy" (1 Sm 13, 22-23). To żona Manoacha musi uspokajać męża obiektywną i opartą na logicznym rozumowaniu argumentacją. W opowieści o kobiecie z Szunem, która wszystkie decyzje dotyczące domu, syna, swoich podróży podejmowała samodzielnie, bez udziału męża, jakby to ona rządziła w tej rodzinie, mąż również był wycofany i niedecyzyjny. Mąż Szunemitki, Manoach, Zachariasz, Elkana, a także Izaak (już jako ojciec Jakuba i Ezawa) są bohaterami, którzy mogą przypominać swoim zachowaniem (biernością, uległością, brakiem zrozumienia, zrzucaniem odpowiedzialności za rodzinę i jej problemy na żonę) niektórych niedojrzałych partnerów czy mężów dzisiejszych kobiet cierpiących z powodu niepłodności. I znów tożsame zachowania, postawy mężów współczesnych i biblijnych odkrywane w terapii narracją biblijną

32 J. Łaba, Niepłodności nasze powszednie, http://portal.tezeusz.pl/blog/nieplodnosci-nasze-powszednie/ (dostęp 26.06.2017). 
mogą spowodować obniżenie poczucia samotności, niezrozumienia, jednostkowej krzywdy w uczestniczkach takowej terapii.

\subsection{ODKRYWANIE NOWEJ TOŻSAMOŚCI OSOBISTEJ POPRZEZ PRZEMIANĘ BOHATEREK}

I mówił Bóg do Abrahama: „Żony twej nie będziesz nazywat imieniem Saraj, lecz imię jej będzie Sara”. (Rdz, 17, 15-16)

To, co niezmiernie ważne w oddziaływaniu narracji wielkich na te małe, osobiste przejawia się w dotarciu do najgłębszych pokładów tożsamości ludzkiej, a mianowicie nie tylko jej świata zachowań, emocji, wglądu w reakcje społeczne, ale też odnajdywanie nowej tożsamości poprzez przemianę wewnętrzną. Przemiana ta obejmuje zazwyczaj całą osobę - inaczej interpretuje ona rzeczywistość (zaczyna postrzegać i rozumieć świat i siebie w odmienny sposób), zmienia się przez to jej reagowanie na sytuacje, dokonuje ona innych niż dotąd wyborów, wybiera zróżnicowany styl życia, co jest zazwyczaj podyktowane odnalezieniem nowego sensu niż dotychczas. Jak uważa Anna Gałdowa, dla tej przemiany wewnętrznej „szczególnie duże znaczenie mają w niej wartości religijne, gdyż dzięki nim może dochodzić do przeformułowania całości ludzkiego doświadczenia oraz nadania mu nowej jakości i sensu”33.

Taka przemiana $\mathrm{w}$ rozumieniu autorki będzie opierała się na ponadczasowych wartościach i cnotach. Czy nie tak działo się właśnie w przypadku przemiany kobiet w Biblii? Chodzi szczególnie o Sarę, która przeszła transformację swojej osobowości zarówno w wymiarze psychicznym, jak i biologicznym, a także w kwestii imienia. Wraz z obietnicą urodzenia potomstwa Saraj zostaje wybrana przez Najwyższego na matkę narodów i otrzymuje nowe imię. Odtąd nie będzie się nazywała Saraj, a Sara - księżniczka, jak przystało na dostojną matriarchinię. Wraz z otrzymaniem nowego imienia i przyjęcia przez Sarę obietnicy urodzenia Izaaka kobieta ta zmienia się z osoby przygaszonej, uwiędłej, zrezygnowanej, starej nie tylko fizycznie, ale i duchowo, w pełną rado-

\footnotetext{
33 A. Gałdowa, Wybrane zagadnienia z psychologii osobowości, Kraków 1999,
} s. 157. 
ści, młodości wewnętrznej, śmiejącą się przyszłą matkę, która uwierzyła w cud. Sara mówi: „Powód do śmiechu dat mi Bóg. Każdy, kto się o tym dowie, śmiać się będzie z mej przyczyny”. I dodawała: „Któż by się ośmielit rzec Abrahamowi: Sara będzie karmiła dzieci piersia, a jednak urodziłam syna mimo podeszłego wieku mego męża" (Rdz, 21, 6-7). Sarę przemienia bojaźń wobec potęgi Wszechmocnego, której to doświadcza namacalnie $\mathrm{w}$ swoim ciele wbrew czasowi i prawom natury. Inaczej jest z Anną matką Samuela, gdyż jej przemiana wewnętrzna dzieje się, gdy nie jest jeszcze w ciąży z Samuelem ani też żaden z posłańców Bożych czy też sam Bóg (jak w przypadku Sary) nie oznajmia jej tej wieści. Anna po prostu opiera swoją przemianę na wierze - całkowitym zaufaniu Temu, który jest, gdy niemalże jak dziecko wylewa cały żal i boleść przed Nim, prosząc Go o syna, którego w tej samej chwili ofiarowuje na wyłączną służbę w świątyni. Wiara Anny w to, że Najwyższy jej nie zawiedzie, sprawia, że z kobiety pogrążonej w depresji staje się pełną godności i pokoju przyszłą matką proroka. Wraca z modlitwy i tak odpowiada kapłanowi Heliemu: „Obyś darzył życzliwościa twoją stużebnicę!” I poszła sobie ta kobieta: jadła i nie miała już twarzy tak [smutnej] jak przedtem (1 Sm 1, 18).

Opowieści o wielkich przemianach psychicznych i duchowych biblijnych kobiet mogą być szansą na to, że uruchomią one procesy przemian w życiu współczesnych niepłodnych. Kobieta, czytając te ponadczasowe historie, ma możliwość odnalezienia własnej opowieści, która poruszy głęboko jej wnętrze, dosłownie dotknie jej serca. Być może pojawią się w tej sytuacji wartości ponadczasowe, takie jak nadzieja czy potrzeba wiary, a może tęsknota za osobową relacją z Najwyższym lub stawianie pytań wobec celów swojego życia ${ }^{34}$. A może po prostu nastąpi zrozumienie tej trudnej sytuacji niepłodności, co pozwoli zaakceptować życie bez dziecka i nadać mu inny bieg. Ale to właśnie dzięki narracji biblijnej o tych, które wieki temu zmagały się z niepłodnością, współczesna kobieta będzie mogła przejść proces terapeutyczny, którego owocami staną się ulga w cierpieniu i nadanie nowego sensu jej niepłodności.

${ }^{34}$ Z. Pawłowski, Rodzaje literackie w Biblii. Ich znaczenie i funkcja $w$ kształtowaniu mowy o Bogu, „Studia Włocławskie”, t. 3, Włocławek 2007, s. 227-236. 


\section{ZAKOŃCZENIE}

Biblijna narracja biograficzna na temat bohaterek zmagających się z problemem niepłodności może bez wątpienia stać się narzędziem terapeutycznym w pracy indywidualnej bądź grupowej z kobietami cierpiącymi w obszarze psychicznym, społecznym i duchowym w następstwie długoletniego braku poczęcia dziecka. Jak wynika z przytoczonych badań, metoda ta spełnia wymogi oddziaływania terapeutycznego terapii narracyjnej. Biblia, jako wielka narracja, pełna jest symbolicznych znaczeń czy metafor, które będą mieć w przebiegu terapii skuteczniejszą moc oddziaływania niż wszelkie nakazy, porady, sugestie terapeutyczne przekazywane wprost. Kobieta niepłodna, żyjąc historiami swoich biblijnych poprzedniczek, ma szansę na uruchomienie w sobie procesu przemiany jej tożsamości jako niespełnionej matki. Powstanie w niej nowa historia własnej niepłodności, którą sama w procesie terapeutycznym będzie indywidualnie tworzyć. Według Krystyny Węgłowskiej-Rzepy: „Tworzenie historii bogatych w symbole pobudza wyobraźnię i uaktywnia motywację. W rezultacie jesteśmy skłonni inaczej spojrzeć na nurtujący nas problem i sposoby jego rozwiązania" ${ }^{35}$. Historie biblijne, o których mowa w niniejszym artykule, nie tylko zachęcą współczesne niepłodne do nowego spojrzenia na ich krytyczną sytuację życiową, ale też będą stymulować do zmiany wewnętrznej, dodawać sił, generować przez to zmianę zewnętrzną - czyli tak ważne w terapii: obniżenie objawów psychopatologicznych i poprawę funkcjonowania. Dlaczego więc w procesie tym nie skorzystać z ponadczasowości Biblii jako narzędzia narracyjnej terapii biograficznej, skoro opiera się ona nie tylko na doświadczeniu wieków, ale też na fakcie, że natura ludzka pozostaje niezmienna ${ }^{36}$ ?

Streszczenie. W artykule zaprezentowano podstawowe założenia teoretyczne, które przemawiają za zasadnością zastosowania biblijnej narracji biograficznej w terapii indywidualnej i grupowej kobiet cierpiących z powodu przedłużającej się niepłodności. Terapia metodą narracji biblijnej z wykorzystaniem historii konkretnych biblijnych niepłodnych bohaterek daje możliwość współczesnym niepłodnym: odreagowania trudnych

${ }^{35}$ K. Węgłowska-Rzepa, Ujęcie z perspektywy psychologii głębi, w: Narracje a wyobrażenia o życiu człowieka, red. M. Straś-Romanowska, B. Bartosz, M. Żurko, s. 226-227.

${ }^{36}$ J. Bagrowicz, S. Jankowski, Pan Bóg Twój wychowuje Ciebie, Toruń 2005, s. 29. 
i bolesnych emocji; obniżenia objawów psychopatologicznych (stany depresyjne i nerwicowe, natręctwa myślowe); poczucia bycia zrozumianą w problemie; zmiany narracji z destrukcyjnych na konstruktywne wokół problemu niepłodności; odkrywania nowej tożsamości jako kobiety; poprawy społecznego funkcjonowania oraz odnalezienia jednostkowego sensu i celu w swojej aktualnej historii życia.

Słowa kluczowe: niepłodność; terapia indywidualna i grupowa; biblijna narracja biograficzna; terapia narracyjna; jednostkowy sens.

Abstract. Biblical Biographical Narrative in Psychotherapy. Great Biblical Narrations of Infertile Women Towards Narration of Modern Women Struggling With Infertility. The article presents basic theoretical assumptions that support the appropriateness of the use of biblical biographical narration in individual and group therapy of women suffering from prolonged infertility. Biblical narrative therapy using specific biblical stories of infertile women gives modern women the opportunity: resolving difficult and painful emotions; reducing psychopathological symptoms (depressive and neurotic states, thoughtlessness); sense of being understood; modification of the narration from destructive to constructive; discovering a new identity; improving social functioning, finding individual meaning of the present life story.

Key words: infertility; individual and group therapy; biblical biographical narrative; narrative therapy; individual sense.

\section{BIBLIOGRAFIA}

Adamiak E., Kobiety w Biblii, Kraków 2006.

Bagrowicz J., Jankowski S., Pan Bóg Twój wychowuje Ciebie, Toruń 2005.

Bartnicki R., Kłósek K., Metody interpretacji Nowego Testamentu, Kraków 2014.

Bartosz B., Doświadczenie macierzyństwa. Analiza narracji autobiograficznych, Wrocław 2002.

Bidzan M., Psychologiczne aspekty niepłodności, Kraków 2006.

Biblia Tysiaclecia. Pismo Święte Starego i Nowego Testamentu, Wydawnictwo Pallotinum, Poznań 1982.

Cierpka A., Narracje rodzinne w procesie kształtowania się tożsamości człowieka, w: Narracja koncepcje i badania psychologiczne, Warszawa 2004.

Doboszyńska A., Kuczmierowska J., Kwaśniewska J., Nadzieja na nowe życie, Kraków 2015.

Dryll E., Cierpka A., Psychologia, dialogowość, pogranicza, Warszawa 2011.

Franciszkańska3.pl, Niełatwe macierzyństwo biblijnych kobiet, http://fra3mobile.fra3test. ceti.pl/ (dostęp 21.05.2018). 
Gałdowa A., Wybrane zagadnienia z psychologii osobowości, Kraków 1999.

Kryteria diagnostyczne z DSM-5, 2015.

Łaba J., Niepłodności nasze powszednie, http://portal.tezeusz.pl/blog/nieplodnosci-nasze-powszednie/ (dostęp 26.06.2017).

Molicka M., Biblioterapia i bajkoterapia, Poznań 2011.

Morgan A., Terapia narracyjna. Wprowadzenie, Warszawa 2011.

Oblicza macierzyństwa, red. D. Kornas-Biela, Lublin 1999.

Orzeszyna, J., Teologiczno-moralny aspekt niepłodności w małżeństwie, Kraków 2005.

Papieska Komisja Biblijna Interpretacja Biblii w Kościele. Dokument Papieskiej Komisji Biblijnej z komentarzem biblistów polskich, red. R. Rubinkiewicz, „Rozprawy i Studia Biblijne", t. 4, Warszawa 1999.

Pawelec B., Pabian W., Niepłodność. Pomoc medyczna i psychologiczna, Sopot 2012.

Pawłowski Z., Hermeneutyczna metoda opowiadania we współczesnej egzegezie, „Collectanea Theologica” 62 (1992) 1, s. 5-17.

Pawłowski Z., Opowiadanie, Bóg i początek: teologia narracyjna Rdz 1-3, „Rozprawy i Studia Biblijne” 13, Warszawa 2003.

Pawłowski Z., Rodzaje literackie w Biblii. Ich znaczenie i funkcja $w$ kształtowaniu mowy o Bogu, „Studia Włocławskie”, t. 3, Włocławek 2007, s. 227-236.

Romaniuk, K., Macierzyństwo w Biblii, w: Macierzyństwo, red. J.Augustyn, Kraków 1998, s. $55-63$.

Straś-Romanowska M., Na tropach psychologii jako nauki humanistycznej, Warszawa 1995. Straś-Romanowska M., Bartosz B., Żurko M., Badania narracyjne w psychologii, Warszawa 2010.

Straś-Romanowska M., Bartosz B., Żurko M., Psychologia małych i wielkich narracji, Warszawa 2010.

Szymik S., Współczesne modele egzegezy biblijnej, Lublin 2013.

Tokarska U., Terapia narracyjna: założenia teoretyczne, metody pracy, obszary zastosowań, „Acta Universitatis Wratislaviensis” 2263 (2000), s. 185-193.

Trzebiński J., Narracja jako sposób rozumienia świata, Gdańsk 2002.

Węgłowska-Rzepa K., Ujęcie z perspektywy psychologii głębi, w: Narracje a wyobrażenia o życiu człowieka, red. M. Straś-Romanowska, B. Bartosz, M. Żurko, s. 225-244. 